\title{
THE DEEP STRUCTURE OF THE NEPA-PELEDUY ARCH OF THE NEPA-BOTUOBA ANTECLISE IN THE DEVELOPMENT OF B.A. SOKOLOV'S HYPOTHESIS
}

\section{R. Marsanova, A. G. Berzin}

\section{M.K. Ammosov North-Eastern Federal University, Yakutsk, Russia}

\begin{abstract}
The studies were conducted in the territory of the Nepa-Peleduy arch (NPA) of the Nepa-Botuoba anteclise (NBA), which is strategically important for the Russian Federation as it contains large and unique hydrocarbon fields, including those essential for the ESPO oil pipeline and the presently under-construction Power of Siberia gas pipeline. Because the hydrocarbon potential of the sedimentary cover is largely exhausted, the aim is now to increase the regional stocks. Verifying the hypothesis of the Corresponding Member of the Russian Academy of Sciences B.A. Sokolov, stating that the allochthonous block of the crystalline basement, overlapping the aulacogen Riphean sediments, lies at the base of the NPA, would open the possibility of increasing the hydrocarbon reserves in the 'subbasement' formations. It would also clarify the controversial nature of the NPA deposits, which have no sediments with a high organic carbon content. In this study, we present a Hilbert transform of a time section of the common midpoint method (CDP) from a fragment of the Batholith-1 geotraverse passing through the Katanga saddle, the NPA and the Pre-Patom trough, as well as geophysical materials and well data from the same profile. Supporting B.A. Sokolov's hypothesis, we confirm the existence of a relict crystalline terrane crosscut by the wells at the base of the NPA and forming the roof of the underlying lower Vendian and Riphean sediment units. Our data clearly document the position of the western side of the inverted paleorift, the thickness of the terrane and the physical characteristics of the underlying sediments. These results are justifying hydrocarbon exploration of the 'subbasement' sediments.
\end{abstract}

Key words: Nepa-Peleduy arch; 'subbasement' sediments; Batholith-1 geotraverse; aulacogen; Talakan oil and gas field 


\title{
ГЛУБИННОЕ СТРОЕНИЕ НЕПСКО-ПЕЛЕДУЙСКОГО СВОДА НЕПСКО-БОТУОБИНСКОЙ АНТЕКЛИЗЫ В РАЗВИТИЕ ГИПОТЕЗЫ Б.А. СОКОЛОВА
}

\author{
М. Р. Марсанова, А. Г. Берзин \\ Северо-Восточный федеральный университет им. М.К. Аммосова, Якутск, Россия
}

\begin{abstract}
Аннотация: Исследования проводились на стратегически важной для РФ территории Непско-Пеледуйского свода (НПС) Непско-Ботуобинской антеклизы, где открыты крупные и уникальные месторождения УВ, в том числе базовые для нефтепровода ВСТО и строящегося газопровода «Сила Сибири». Проблема заключается в наращивании запасов, так как УВ-потенциал осадочного чехла в значительной мере исчерпан. Доказательство гипотезы члена-корреспондента РАН Б.А. Соколова о том, что в основании НПС залегает аллохтонная кристаллическая пластина, перекрывающая авлакоген с рифейскими отложениями, открывает возможность наращивания запасов УВ в «подфундаментных» образованиях свода, а также уточнения дискуссионной природы месторождений НПС, в осадочном чехле которого отсутствуют отложения с высоким содержанием органического углерода. Рассматривается Гильберт-преобразование временного разреза МоГТ по фрагменту геотраверса «Батолит-1», проходящего через Катангскую седловину, НПС и Предпатомский прогиб, а также геофизические материалы и данные скважин на нем. На основе оригинальных построений по геолого-геофизическим данным и моделирования, увязываемых в развитие гипотезы с эволюцией авлакогена и покрывающей его аллохтонной пластины, получены аргументы подтверждения существования кристаллической пластины, вскрываемой скважинами в основании НПС, и развития под ней отложений нижнего венда и рифея; намечено положение западного борта инверсионного палеорифта, оценена толщина пластины и промысловые характеристики отложений, прогнозируемые под ней, что может служить обоснованием целесообразности разведки «подфундаментных» отложений.
\end{abstract}

Ключевые слова: Непско-Пеледуйский свод; «подфундаментные» отложения; геотраверс «Батолит-1»; авлакоген; Чаяндинское месторождение нефти и газа

\section{INTRODUCTION}

The studies were conducted in the territory of the Nepa-Peleduy arch (NPA) of the Nepa-Botuoba anteclise (NBA) within the southern reach of the Siberian platform. That region is strategically important for the Russian Federation for it represents $2 / 3$ of the gas reserves and all NBA oil reserves, including the large Verkhnechonskoye and Talakanskoye gas and oil fields and the unique Chayandinskoye oil and gas fields. Those form the main supply source for the ESPO pipeline and the presently under construction Power of Siberia gas pipeline [Vorobyov et al., 2006; Karagodin, 1980] (Fig. 1). The problem lies in the further increase of hydrocarbon reserves, because the sediment cover of the dome is well studied and the prospects for the discovery of new large deposits in it are small. With that objective, it becomes important to include in the prospection scheme the crystalline basement and the deep formations, where non-conventional formation of hydrocarbons is possible [Alekseev et al., 2002; Aleksandrov et al., 2014; Ivannikov, Kuznetsov, 2010; Sokolov, 2001]. The scientific side of such exploration may be the identification of the controversial nature of the NPA deposits located near the basement in a lowcapacity sediment cover with a low content of organic carbon and the absence of conditions for the longrange migration of hydrocarbons.

In the 1990s, the Corresponding Member of the RAS B.A. Sokolov put forward a hypothesis to explain the genesis of the Nepa-Peleduy arch. He postulated that the NPA base that was penetrated by wells is an allochthonous block of the crystalline basement, which was pulled out of the Pre-Patom trough in Pre-Vendian times to the southern part of the Irkineevsk-Katanga Riphean paleorift. The source of organic matter would be the Riphean deposits under the basement allochthon, some of which would migrate upward through fractures, forming oil and gas deposits within the sedimentary cover, represented by the Vendian terrigenous complex and Vendian-Cambrian carbonate rocks, which lack organic matter. In this model, a significant potential under the allochthon should remain unclaimed [Sokolov, 2001].

Later studies using the geological and geophysical data and geological-density modelling confirmed Sokolov's hypothesis on the existence of a paleorift overlaid 


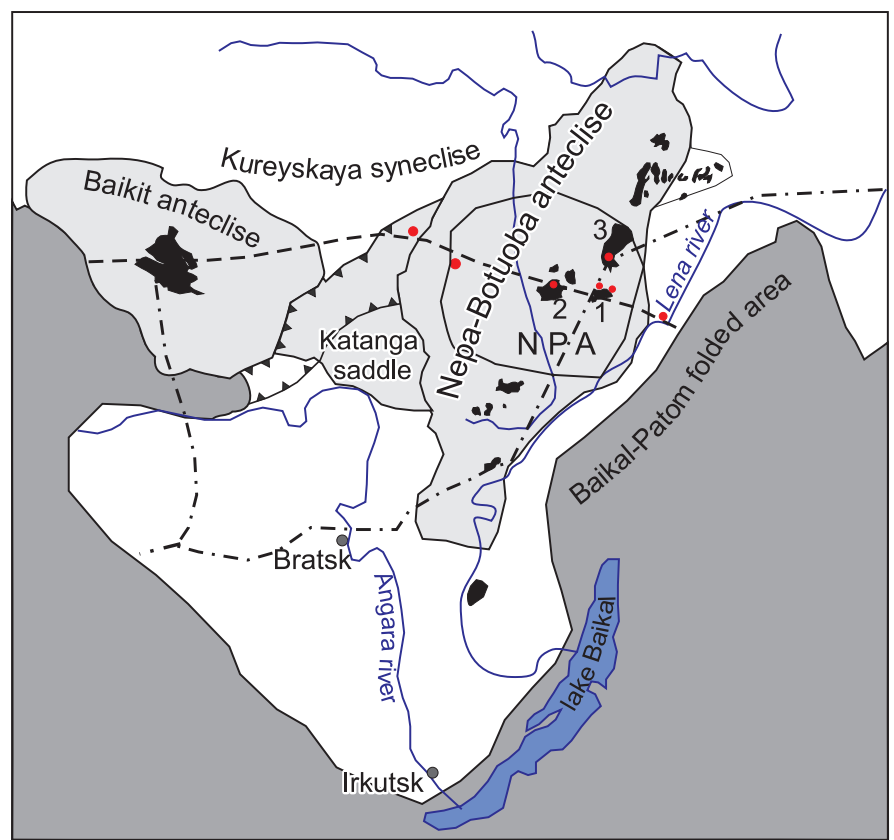

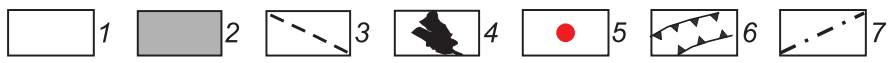

by an allochthonous block of crystalline basement at the base of the NPA. However, the model of a deep structure built on these data differs in the structure and dynamics of the formation. The allochthonous cover is a subhorizontal relict crystalline terrane from the denudative allochthonous block of the granitegneiss layer of the crust, pulled from the Pre-Patom basement trough to the paleorift during the Late Riphean. At the same time, the authors closely link the genesis of the terrane with the expected evolution of the paleorift [Berzin et al., 2015] (Fig. 2).

The results obtained are indirect evidence of the hypothesis, and the model constructed is too schematic to allow solving a range of detailed problems associated with Sokolov's model. A more substantive model would require a reliable confirmation of the existence of a crystalline terrane that is opened by wells on the roof, an assessment of its thickness, and a clarification of the occurrence and the field characteristics of the sediments under the terrane. The purpose of our research is to substantiate the prerequisites to support the exploration of 'subfoundation' deposits at the base of the NPA, search them for hydrocarbon deposits and contribute to the growth of the raw material resources in the eastern regions of the Russian Federation.

\section{METHODS}

The geological structure of the NPA territory on the eastern fragment of the Batholith-1 geotraverse was studied, from the junction zone of the anteclise with the Pre-Patom trough (eastern NBA side) to the junction
Fig. 1. Nepa-Botuoba anteclise and associated super order structures with the discussed geological load.

1 - Siberian platform; 2 - fold framing platform; 3 - Batholith-1 geotraverse; 4 - oil and gas fields: 1 - Talakanskoye, 2 - Verkhnechonskoye, 3 - Chayandinskoye; 5 - wells, on which the SDS are built; 6 - Irkineev-Chadobetsk aulacogen; 7 - ESPO gas pipeline. NPA - Nepa-Peleduy arch.

Рис. 1. Непско-Ботуобинская антеклиза и сопряженные надпорядковые структуры с обсуждаемой геологической нагрузкой.

1 - Сибирская платформа; 2 - складчатое обрамление платформы; 3 - геотраверс «Батолит-1»; 4 - месторождения нефти и газа, в том числе упоминаемые в тексте: 1 - Талаканское, 2 - Верхнечонское, 3 - Чаяндинское; 5 - скважины, на которых построены развертки СГР; 6 - Иркинеево-Чадобецкий авлакоген; 7 - газопровод ВСТО. NPA - Непско-Пеледуйский свод.

with the Katanga saddle (western NBA side) [Detkov et al., 2007] (see Fig. 1). Common Depth Point (CDP) seismic sections, profile gravity magnetic observations and deep well data logging on the profile were analysed to derive stratigraphic breakdowns, correlation schemes and geological modelling.

\section{DATA PROCESSING METHODS}

Hilbert transforms of the seismic sections, stratigraphic correlation and cyclicality were analysed using the RITM program [Berzin et al., 2011; Afanasiev, 1984]. A feature of the program that builds spectral depth scans (SDS) was used to study the cyclic nature of the sediment accumulation processes by continuously tracking the depth of the metric parameter $\mathrm{R}$ (correlation radius), calculated in several logging curve analysis windows [Berzin et al., 2011]. The acoustic sounding $\log$ (ASL) curve is the base for constructing SDS for the terrigenous-sulfate-carbonate section of the NPA. The comparison of SDS with a lithological section and the results of numerical modelling suggest that they reflect changes in the gradient (coarseness) and/or disjunctiveness (number of layers per unit length) in the sedimentary cover, as well as the directions of sediment progradation or retrogradation, which form facially specific lithological series of sediments [Berzin S.A., Berzin A.G., 2011; Berzin et al., 2011]. The SDSs were used to establish the characteristics of cyclic sediment facies variations of the Vendian-Cambrian Chayandinskoye, Talakanskoye and Verkhnevilyuchanskoye formations studied by deep drilling [Berzin et al., 2011]. 
(a)

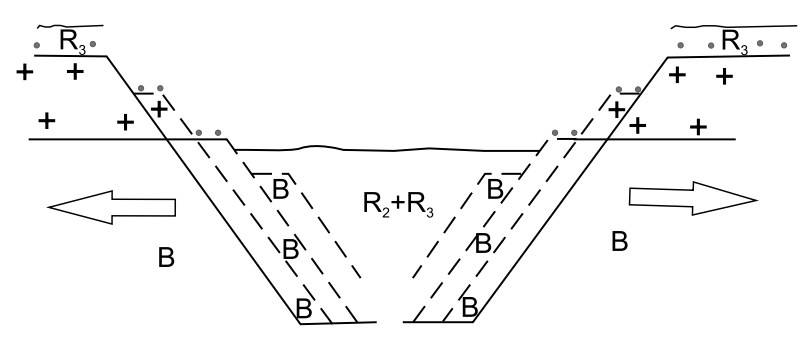

(8)

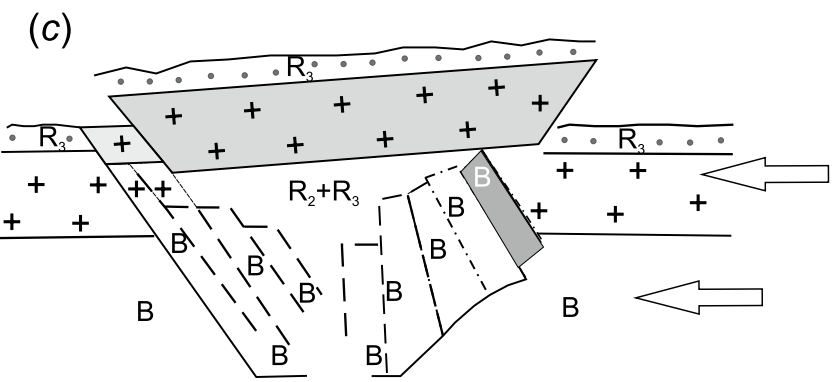

$(d)$
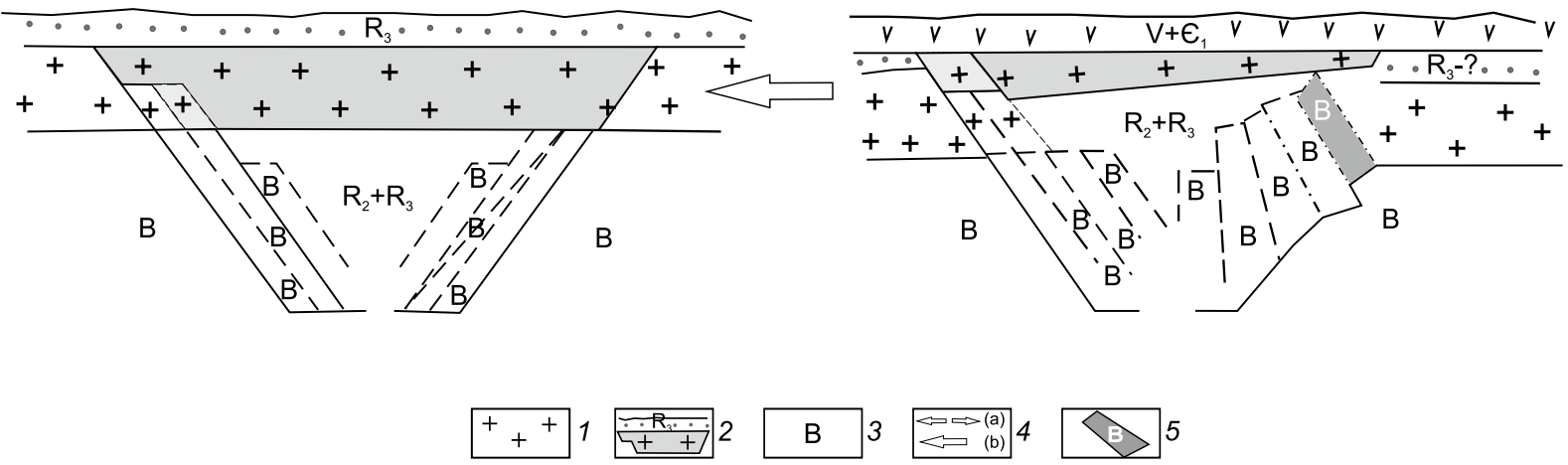

Fig. 2. Model of paleorift evolution and formation of a relict crystalline terrane [Berzin et al., 2013].

(a) - the stage of crustal stretching, rifting and accumulation of Riphean deposits R2 and R3; (b) - the stage of tangential compression from the Baikal-Patom folded area and the overlapping of the rift with the granite-gneiss block of the earth's crust; (c) - rift deformation and extrusion of the thrust block up (according to [Ramsay, Huber, 1987]); (d) - denudation of the protruding part of the block and peneplanation of its surface. 1 - granite-gneiss layer; 2 - thrust granite-gneiss block; 3 - granulite-basite layer; 4 - tangential stresses: $\mathrm{a}$ - stretching, $\mathrm{b}$ - compression; 5 - granulite-basite block of sub-vertical dip protruding under the terrane, creating anomaly 1 of the field $\Delta \mathrm{T}$ along the Batholith-1 profile (see Fig. 3), the position of which is determined by the eastern side of the aulacogen.

Рис. 2. Модель эволюции палеорифта и образования реликтовой кристаллической пластины [Berzin et al., 2013].

$(a)$ - стадия растяжения земной коры, образования рифта и накопления рифейских отложений R2 и R3; (b) - стадия тангенциального сжатия со стороны Байкало-Патомской складчатой области и перекрытия рифта гранито-гнейсовым блоком земной коры; (c) - деформация рифта и выдавливание надвинутого блока вверх [Ramsay, Huber, 1987]; (d) - денудация выступающей части блока и пенепленизация его поверхности. Блоки: 1 - гранитогнейсовый слой Земли; 2 - надвинутый блок; 3 - гранулитобазитовый слой Земли; 4 - тангенциальные напряжения: a - растяжения, b - сжатия; 5 - выступающий под пластину гранулитобазитовый блок субвертикального падения, создающий аномалию 1 поля $\Delta \mathrm{T}$ по профилю «Батолит-1» (см. рис. 3), положение которого определяет восточный борт авлакогена.

\section{RESULTS}

The results of our analysis largely depend on the geological interpretation of the phenomenon observed in the Hilbert transform of the eastern fragment of the Batholith-1 geotraverse. Pronounced 'subbasement' reflections are imaged below the penetration marks of the roof of crystalline rocks in the territory of the Nepa-Peleduy arch. Other features are also noted that do not meet the traditional ideas of the arch as an elevated part of the larger platform structure of the syndepositional development with a consolidated foundation (Fig. 3).

1. The seismic section of the wells drilled on the NPA fields shows that the crystalline rocks are penetrated at close occurrence times. At the same time, the opening line is located almost horizontally and discordantly in relation to the monoclinal lifting of the re- flecting horizons to the east of Well 2-SN (2-CH) Well 826-Tl.

2. Under the penetration line of the crystalline rocks, there are two pronounced reflecting horizons in the section, which in the deep seismic-geological section of the western fragment of the geotraverse in the Katanga saddle are classified as horizons B (sub-Osinsky salts of the Usolye suite) and R0 (Vend-Paleozoic base complex) [Larkin, Valchak, 2007]. At the same time, horizon Bwith the stratigraphic analogues of the sub-Osinsky salts in the Talakan area was found at much higher levels, while the reflections of the lower Vendian revealed by Well 804 correlate with horizon B.

3. In the proposed junction zone of the western side of the Nepa-Botuoba anteclise (PK $810 \mathrm{~km}$ ?) and the eastern side of the Katanga saddle (PK $710 \mathrm{~km}$ ), there is a significant deepening of the surface of the crystalline rocks from a depth of $1500 \mathrm{~m}$ to a depth of $3500 \mathrm{~m}$, 


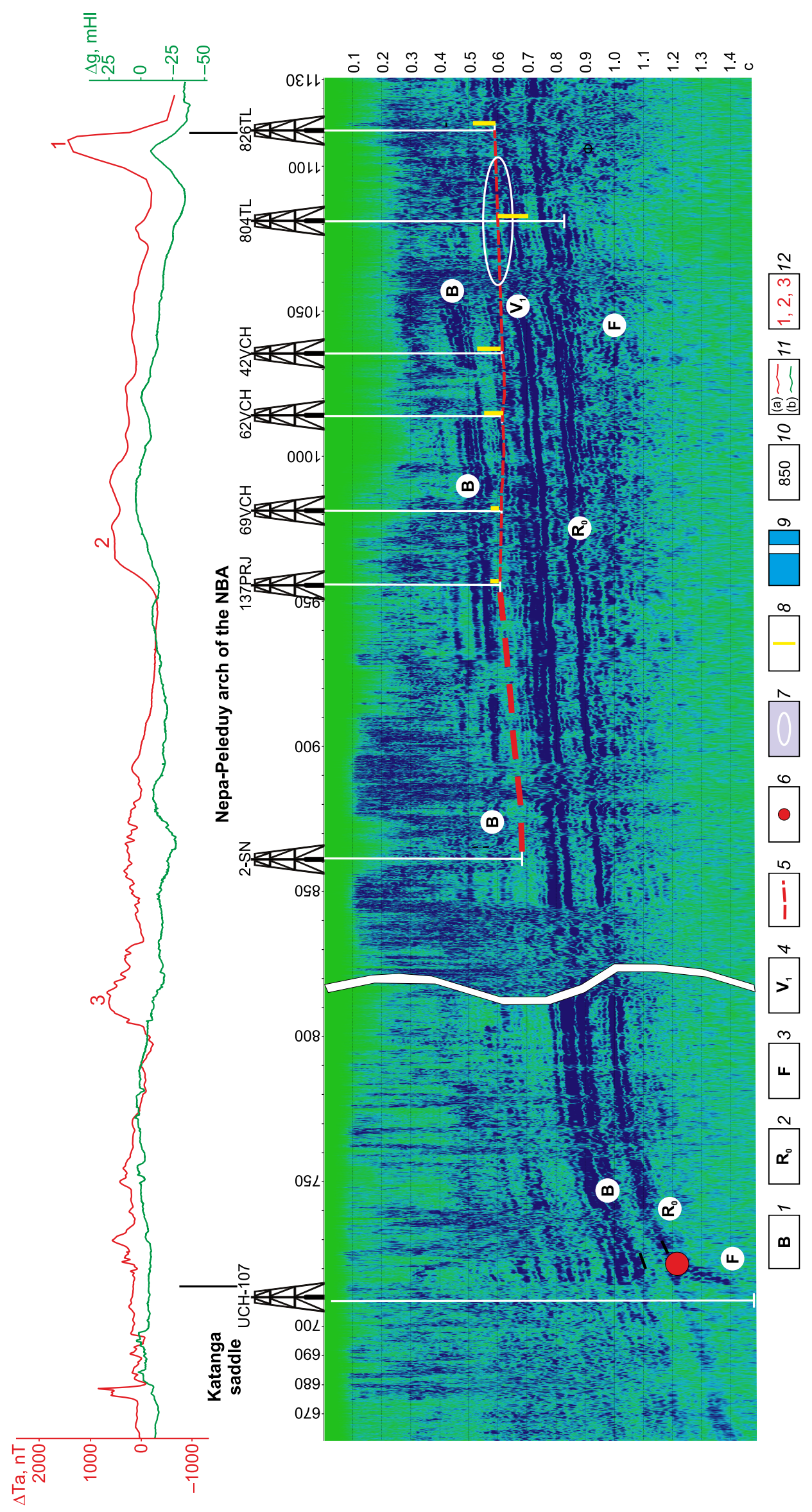

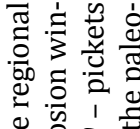

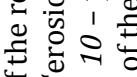

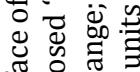

言 을

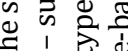

的艺

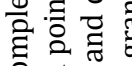

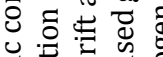

论

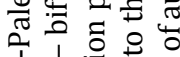

密

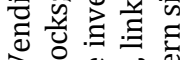

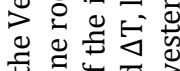

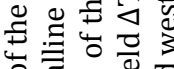

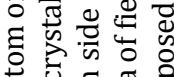

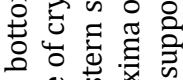

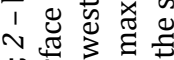

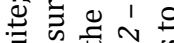

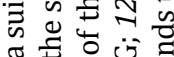

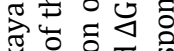

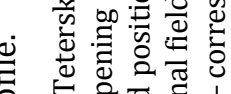

运

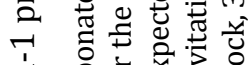

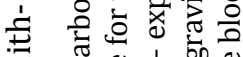

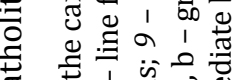

范

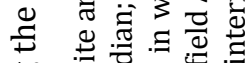

a

을

更

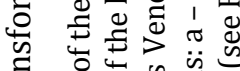

त्ञ

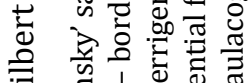

表

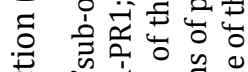

ज.

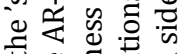

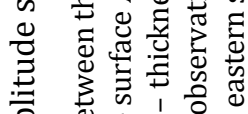

言

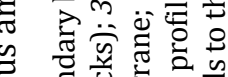

尊

胥

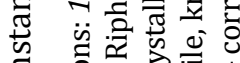

政

F

m

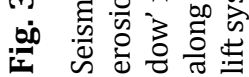

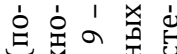

당

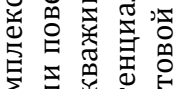

를

욤

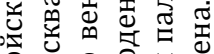

엉요인

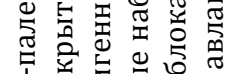

15

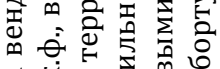

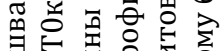

응

응

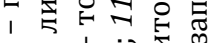

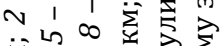

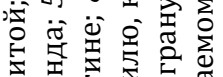

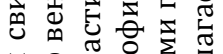

응인들을

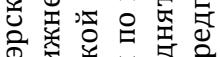

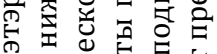

(5)

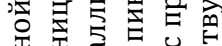

商

교

중 0 잉

西

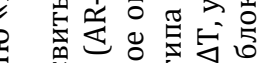

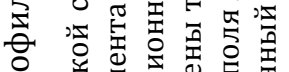

-

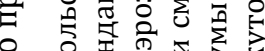

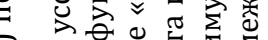

ब

5 일

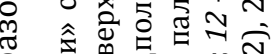

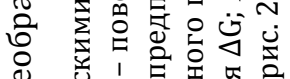

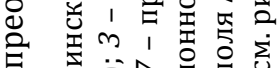

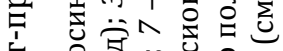

웅 웅

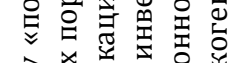

定希

원

$\Sigma$ 현

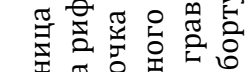

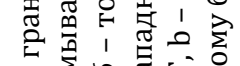

1 일

$\forall$. 엉

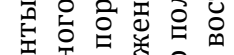

일

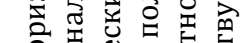

언

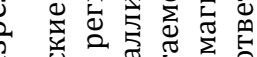

过柁

m

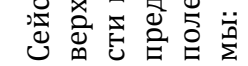




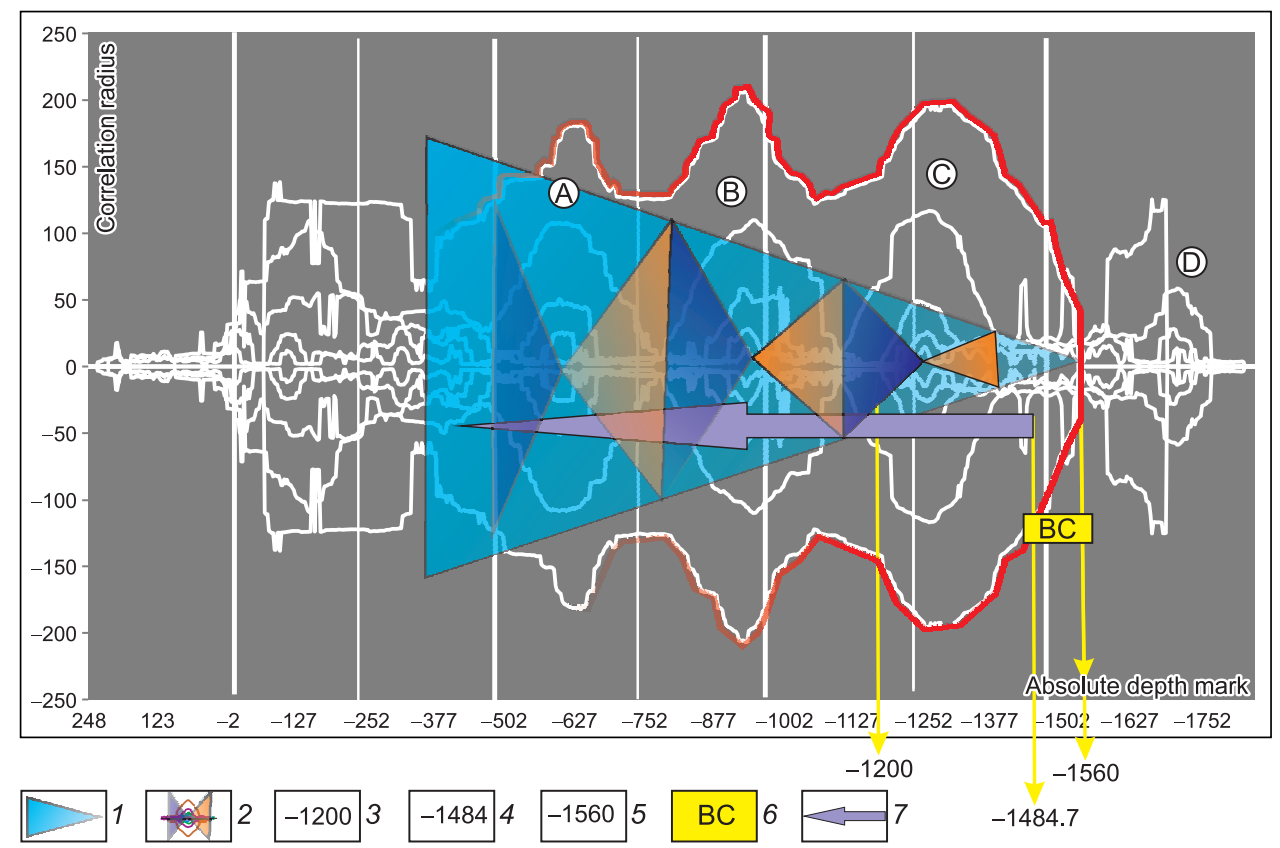

Fig. 4. Spectral depth scan of acoustic logging of Well 804 in the Talakan area, and elements of interpretation.

1 - mega-procyclite of the Vend - Lower Cambrian; 2 - synchronous growths of SDS curves (reprocyclites), associated with potential oil and gas reservoirs: A - Tolbachansky, B - Osinsky, C - Botuobinsky, D - Riphean; 3-5 - absolute reference marks: 3 - average value of the roof of crystalline rocks in adjacent wells with Well 804, 4 - borders of Vendian-Cambrian according to drilling data, 5 - mark of the megaprocyclite closure; 6 - blurred cyclicality; 7 - direction of sedimentation.

Рис. 4. Спектрально-глубинная развертка по акустическому каротажу скв. № 804 на Талаканской площади с элементами интерпретации.

1 - мегапроциклит венд - нижний кембрий; 2 - синхронные разрастания кривых СГР (репроциклиты), увязываемые с потенциальными нефтегазовыми резервуарами: А - Толбачанский, В - Осинский, С - Ботуобинский, D - Рифейский; 3-5 - абсолютные отметки реперов: 3 - среднего значения кровли кристаллических пород по смежным со скв. № 804 скважинам, 4 - границы венд - кембрий по данным бурения, 5 - замыкания мегапроциклита; 6 - размытая цикличность; 7 - направление седиментации.

which, with the consolidated foundation on the arch, should be reflected in the gravitational field by the gravitational step, but it is not reflected (see Fig. 3).

The noted features in the framework of Sokolov's model of the NPA geological structure need to be explained, and therefore the geological arguments supporting the hypothesis and, in the first place, asserting the reality of the existence of the allochthonous terrane (and hence the paleorift under it) and its mechanical and petrographic parameters are important. One of those arguments is based on identifying the regional erosion surface between the Riphean and Vendian deposits [Anuprienko et al., 1989; Kontorovich et al., 1981] and establishing its position in the section in the case of a consolidated foundation and an allochthonous terrane. This argument is supported by the data from Well No. 804 in the Talakan area, which reached the geological section below the roof of crystalline rocks, fixed on neighbouring wells, passed about $660 \mathrm{~m}$ along it and supposedly stopped in Riphean rocks (R2?).

It is assumed that the well reached one of the graben-like structures of the foundation where Riphean formations have been preserved, since the Nepa-Botu- oba anteclise in the Riphean time was the largest area of denudation [Anuprienko et al., 1989; Detkov et al., 2007]. An alternative point of view is that the well reached an erosion 'window' formed during the denudation of the allochthonous block down to a peneplaned crystalline terrane [Berzin et al., 2015].

Due to an ambiguity of the age determination of several lower Vendian suites in the Siberian platform's inner regions, it is important to establish a regional erosion surface in Well 804 as a reference boundary between the Riphean and the Vendian [Shemin, 2007]. In our study, the RITM program was used to built a spectral depth scan (SDS) of acoustic logging data of Well 804. The scan allowed clarifying the existing ideas about the Vendian-Lower Cambrian megacycle [Melnikov et al., 1978; Karagodin, 1980; Melnikov et al., 1981; Romanovsky, 1988] and establishing the position of the regional erosion boundary at $-1560 \mathrm{~m}$ based on the onset of megacycles successions (closure of the analysis windows) deeper than its occurrence (Fig. 4).

On the SDS in the section of the Vendian and Cambrian, one of the largest Vendian - Lower Cambrian mega-cyclite covering the entire sedimentary cover is 


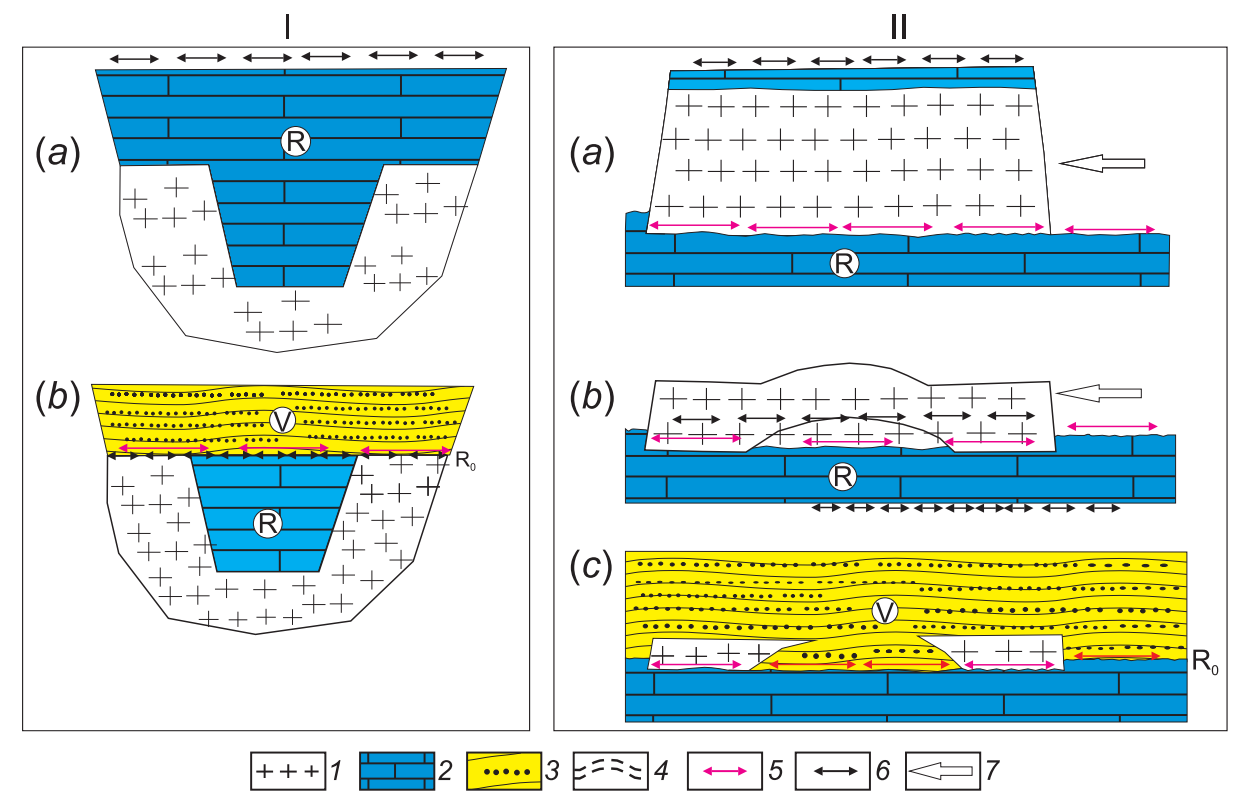

Fig. 5. Models of sedimentation.

I - a graben in a consolidated crystalline basement: $(a)$ - filling of the graben and the supra-foundation space with Riphean formations; (b) - Riphean sediments washed up to the level of graben shoulders and Vendian sediment accumulation.

II - an erosion window in the crystalline terrane: $(a)$ - allochthonic granite-gneiss block of the crust on the diffuse autochthonous surface of the Riphean sediments; $(b)$ - washing of the block to the state of a crystalline terrane experiencing transverse bending deformation; $(c)$ - opening the erosion window during the subsequent erosion and the formation of Vendian deposits on the diffuse surface of the Riphean rocks.

1 - crystalline base (Archean base or denudated terrane); 2 - Riphean rocks; 3 - Vendian rocks; 4 - transverse deformation of the crystalline terrane; 5 - regional boundary between Riphean and Vendian on the blurred surface of Riphean formations inside the erosion 'window'; 6 - levels of erosion; 7 - compression direction.

\section{Рис. 5. Модели осадконакопления.}

I - в случае грабена в консолидированном кристаллическом фундаменте: $(a)$ - заполнение грабена и надфундаментного пространства рифейскими образованиями; $(b)$ - размыв рифейских отложений до уровня плеч грабена и накопление отложений венда.

II - в случае зрозионного окна в кристаллической пластине: $(a)$ - аллохтонный гранитогнейсовый блок земной коры на размытой автохтонной поверхности рифейских отложений; $(b)$ - размыв блока до состояния кристаллической пластины, испытывающей деформацию в форме поперечного изгиба; $(c)$ - вскрытие эрозионного окна при последующем размыве и формирование вендских отложений на размытой поверхности рифейских пород.

1 - кристаллическое основание (архейский фундамент или денудированная пластина); 2 - породы рифея; 3 - породы венда; 4 поперечная деформация кристаллической пластины; 5 - региональная граница раздела рифея и венда на размытой поверхности рифейских образований внутри эрозионного «окна»; 6- уровни размыва; 7 - направление сжатия.

distinguished in the Talakan area. It includes three 1storder macro-cyclites (reprocyclites). Fundamentally new is the inclusion of fuzzy sediments of the lower Vendian in the SDS mega-cyclites (Fig. 4). Synchronous growths of parameter $\mathrm{R}$ in different analysis windows are timed to the borders of macro-cyclites, where the transition from regressive to transgressive sedimentation occurs. These features are linked to potential oil and gas reservoirs: A - Tolbachansky, B - Osinsky, C Botuobinsky, D - Riphean, which were described in the studies of the southern regions of the Siberian platform (e.g. [Shemin, 2007]).

To explain the geometry and position of the erosion level at $-1560 \mathrm{~m}$ and that of the top of the crystalline rocks reached by neighbouring wells, models showing sedimentation in Well 804 were constructed and tested for: (1) a graben in a consolidated foundation, and (2) an erosion window in the crystalline terrane (Fig. 5). The simulation results indicate that the position of the regional erosion layer between the Vendian and Riphean below the top of the crystalline rocks can be explained only in the case of an erosion window in the crystalline terrane and is an argument for the existence of such a window but also of the slab of crystalline rocks itself. According to the models, such a 'window' was formed in the process of erosion of the granitegneiss block to the state of a terrane of critical thickness, when the terrane experienced warping in some 


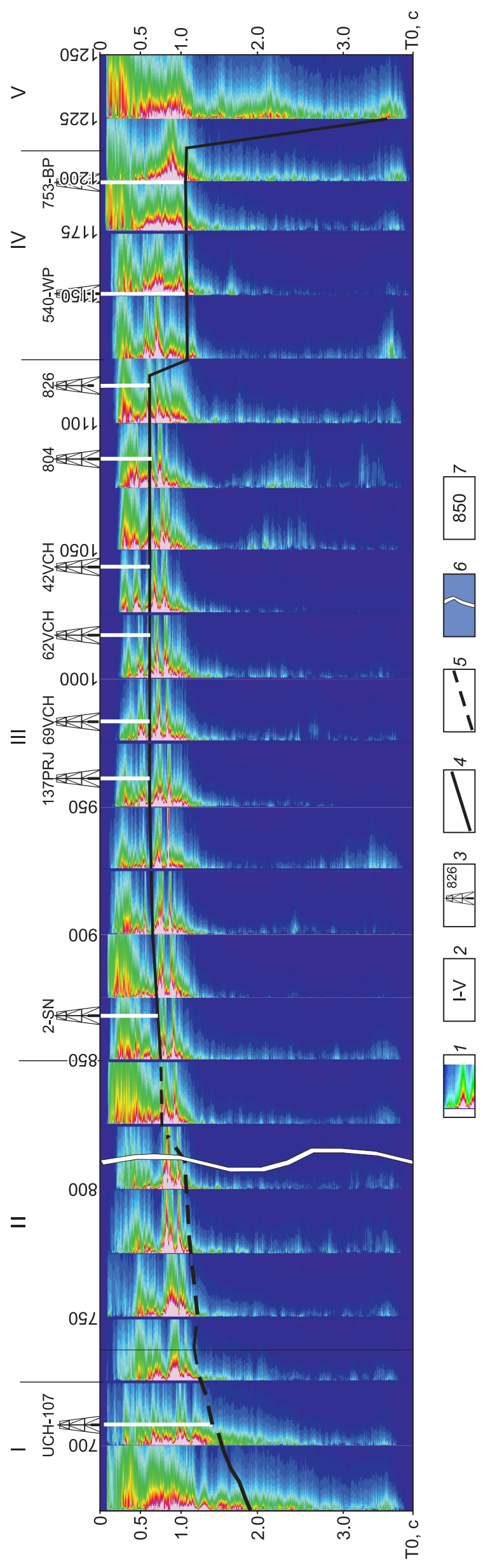

E气 월

岁

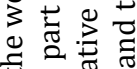

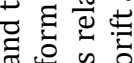

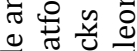

$\frac{\pi}{2} \frac{\pi}{2} \stackrel{\frac{\pi}{2}}{0}$

$\stackrel{\infty}{\infty} \geq \Xi$

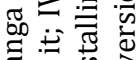

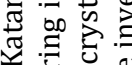

ช

ఫ

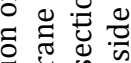

营昰

盯范

记芯氙

\&

유응

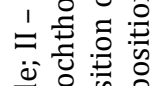

量 券

可

造䨔 的

䒕造苛

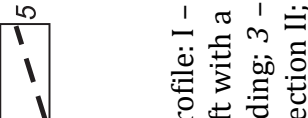

는

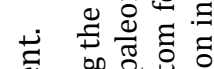

$\prod^{+}$

0020.0

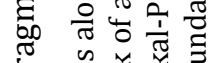

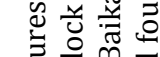

氙응 要

这

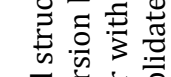

तु

.

$\geq$

迥

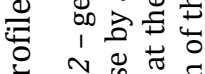

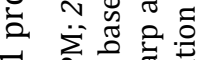

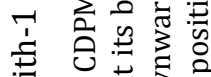

考

苛

¿ ह

कo

을 导苛产

ฮ छ

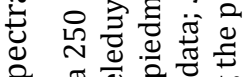

की

व $03 \frac{0}{0}$

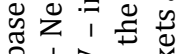

ㄴ $1>0$ 过

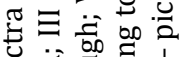

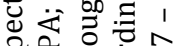

क合

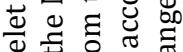

त范苛

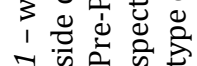

๘ั

氞焉恣

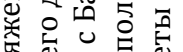

总恣寻焉

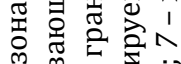

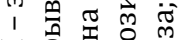

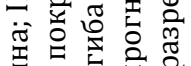

记完

告是的焉

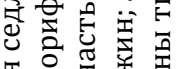

ฮั

盯

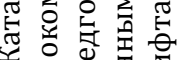

1 占沓

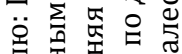

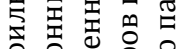

웡욘윤

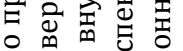

吉>을

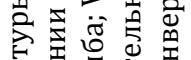

资

년

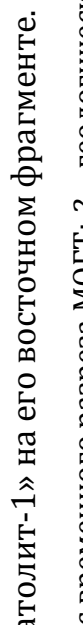

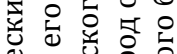

焉穿

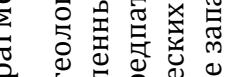

○.

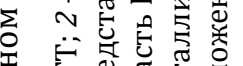

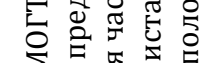

$\sum_{\pi}$ 过

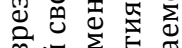

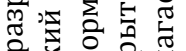

0 出 5

닝

要空志

造焉

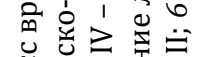

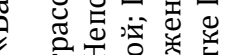

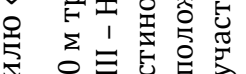

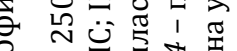

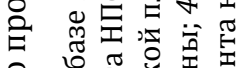

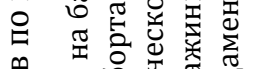

๓

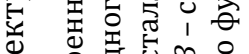

은

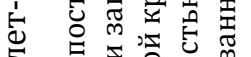

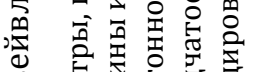

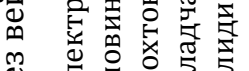

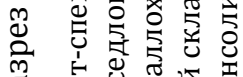

م.

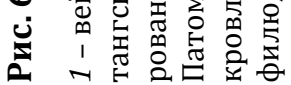


areas due to tangential forces and thus detached from the autochthon, and the subsequent erosion opened it. The estimated thickness of the terrane in the 'window' area is $330 \mathrm{~m}$. The simulated occurrence of the allochthone crystalline terrane suggests that underneath at the NPA base, there is an inverted paleorift system containing lower Vendian and Riphean deposits, and confirms that reflections from such a system on the time section are real (see Fig. 3).

The non-anomalous field $\Delta G$ in the interval of the difference in the depth of the crystalline rocks roof (pickets $680-710 \mathrm{~km}$ ) confirms that the wells in the NPA territory do not reach the true crystalline basement but penetrate to the roof of a subparallel crystalline terrane of relatively small thickness. The very surface of the basic granulitic blocks of the paleorift system lies deep here. This is evidenced by the observed magnetic field curve $\Delta \mathrm{T}$, on which three maxima are allocated. These can be associated with the rise of basic granulitic facies rocks, of which the 1st maximum corresponds to the eastern side of the paleorift system, the 2nd to the intermediate block, and the 3rd, presumably, corresponds to the western side (see Fig. 3).

According to the new NPA deep-seated model, the horizon B in the Katanga saddle cannot be correlated to stratigraphic analogues in the Talakanskoye and Verkhnechonskoye deposits due to the difference in the types of geological sections in the junction zone of the western side of the NPA and the Katanga saddle to the west of Well 2-SN (2-CH) in the Sanar area. In this zone, the position of the western side of the inverted aulacogen and the termination of the allochthonous terrane covering it and, accordingly, the change of the geological section are assumed as shown in Fig. 3. This assumption is based on the time section of the integral wavelet spectra for the considered fragment of the Batholith-1 geotraverse that reflects the distribution of the energy characteristics of the reflected waves in depth (Fig. 6).

It has been established that the conditional opening line by the wells of the roof of crystalline rocks in the NPA territory (structure III) is located in the middle of the spectra, thereby fixing the energy of 'subbasement' reflections from sedimentary formations and the small thickness of the crystalline rocks covering them. On the contrary, in the wells located in the Pre-Patom trough (structure IV), the opening line shifts to the end of the spectra, positioning the true crystalline basement. This feature, in conjunction with others, allowed establishing the position of the eastern side of the paleorift system and the termination of the relic allochthon terrane covering it east of Well 826 [Berzin et al., 2015]. The occurrence of this feature is logically expected toward the west of the section fragment in the joint area of the NPA and the Katanga saddle, where the depth of the surface of crystalline rocks in Well 2 in the Sanar area is located on the wavelet section in the middle of the spectrum, and in Well YuCh-107 in the Katanga saddle, it descends to the end of the spectrum (see Fig. 4). The probable position of the western side and the change of types of the geological section are specified on PK 810 with the involvement of other geophysical features: changes in the dynamics of the reflected waves on the reference horizons B and R0 and the position of the 3rd maximum of the field $\Delta \mathrm{T}$ (see Fig. 3).

\section{CONCLUSIONS}

In our study of the eastern fragment of the time section of the CDPM imaged by the Batholith-1 geotraverse, we have confirmed the validity of the scientific ideas proposed by B.A. Sokolov about the existence of a relict crystalline terrane from the base of the NepaPeleduy arch. This denuded allochthonous granitegneiss block overlies the paleorift system that contains lower Vendian and Riphean sediments.

According to our estimations, the thickness of the crystalline plate is $330 \mathrm{~m}$. The lower Vendian and Riphean deposits predicted under the terrane need to be further investigated as potentially productive reservoirs. The revealed position of the western side of the inverted aulacogen and the termination of the allochthonous plate covering it suggest a different geological section further west. The results of our studies can be used as an additional justification to develop target drilling of deep wells and discover 'subbasement' deposits in the territory of the Nepa-Peleduy arch of the Nepa-Botuoba anteclise.

\section{REFERENCES}

Afanasiev S.L. (Ed.), 1984. Mathematical Methods of Cyclicity Analysis in Geology. Nauka, Moscow, 178 p. (in Russian) [Математические методы анализа цикличности в геологии / Ред. С.Л. Афанасьев. М.: Наука, 1984. 178 с.].

Aleksandrov B.L., Labazanov M.M., Khasanov M.A., Ezirbaev T.B., Germakhanova D.U., 2014. The main arguments in favor of the theory of abiogenic origin of hydrocarbons. Geology, Geophysics and Development of Oil and Gas Fields (4), 64-67 (in Russian) [Александров Б.Л., Лабазанов М.М., Хасанов М.А., Эзирбаев Т.Б., Гермаханова Д.У. Основные доводы в пользу теории абиогенного происхождения углеводородов // Геология, геофизика и разработка небтяных и газовых месторождений. 2014. № 4. С. 64-67].

Alekseev F.N., Berzin A.G., Sitnikov V.S., 2002. Natural aggregates and associations of hydrocarbon deposits. In: New ideas in geology and geochemistry of oil and gas. Proceedings of the 6th International Conference. Vol. 1. GEOS, 
Moscow, p. 21-25 (in Russian) [Алексеев Ф.Н., Берзин А.Г., Ситников В.С. Природные совокупности и ассоциации залежей углеводородов // Новые идеи в геологии и геохимии нефти и газа: Материалы VI международной конференции. М.: ГЕОС, 2002. Т. 1. С. 21-25].

Anuprienko A.A., Bakin E.V., Barsukov V.V. et al., 1989. Geology and Geochemistry of Crude Oils of the Northeastern Part of Nepa-Botuoba Anteclise. Yakutian Science Center, Yakutsk, 168 p. (in Russian) [Ануприенко А.А., Бакин В.E., Барсуков В.B. и др. Геология и геохимия нефтей северо-восточной части Непско-Ботуобинской антеклизы. Якутск: ЯНЦ, 1989.168 с.].

Berzin A.G., Illarionova M.G., Ivanov I.S., Marsanova M.R., Berzin S.A., 2015. Geological and geophysical background of the unique oil and gas potential of subbasement formations of the Nepa-Peleduy arch. Razvedka i Okhrana Nedr (Exploration and Conservation of Mineral Resources) (11), 17-22 (in Russian) [Берзин А.Г., Илларионова М.Г., Иванов И.С., Марсанова М.Р., Берзин С.А. Геолого-геофизические предпосылки уникального нефтегазового потенциала подфундаментных образований Непско-Пеледуйского свода // Разведка и охрана недр. 2015. № 11. C. 17-22].

Berzin A.G., Ivanov I.S., Arkhipova T.A., 2013. About the deep structure of the Western segment of Pre-Patom trough and the adjacent part of the Nepa-Peleduy arch. Science and Education (2), 7-14 (in Russian) [Берзин А.Г., Иванов И.С., Архипова Т.А. О глубинном строении западного сегмента Предпатомского прогиба и прилегающей части Непско-Пеледуйского свода // Наука и образование. 2013. № 2. С. 7-14].

Berzin A.G., Sitnikov V.S., Berzin S.A., 2011. Experience in the use of spectral-depth scans of well logging data for solving oil and gas prospecting problems on the Siberian platform. Karotazhnik (Well Logger) (8), 10-24 (in Russian) [Берзин А.Г., Ситников В.С., Берзин С.А. Опыт использования спектрально-глубинных разверток данных каротажа для решения нефтегазопоисковых задач на Сибирской платформе // Каротажник. 2011. № 8. C. 10-24].

Berzin S.A., Berzin A.G., 2011. Models of the cyclic structure of the Vendian-Cambrian deposits of the Nepa-Peleduy arch according to the wells logging (Siberian platform). Otechestvennaya Geologiya (Russian Geology) (6), 87-96 (in Russian) [Берзин C.A., Берзин А.Г. Модели циклического строения отложений венда - кембрия месторождений Непско-Пеледуйского свода по данным каротажа скважин (Сибирская платформа) // Отечественная геология. 2011. № 6. С. 87-96].

Detkov V.A., Valchak V.I., Goryunov N.A., Evgrafov A.A., 2007. Some features of the Earth's crust and upper mantle structure of the southern part of the Siberian platform in Batolit and Altai - Severnaya Zemlya sections. In: Models of the Earth's crust and upper mantle by deep seismic profiling. Proceedings of the International scientific-practical seminar. VSEGEI, Saint Petersburg, p. 26-31 (in Russian] [Детков В.А., Вальчак В.И., Горюнов Н.А., Евграфов А.А. Особенности строения земной коры и верхней мантии юга Сибирской платформы в сечении опорных маршрутов Батолит и Алтай - Северная Земля // Модели земной коры и верхней мантии по результатам глубинного сейсмопрофилирования: Материалы Международного научно-практического семинара. СПб.: ВСЕГЕИ, 2007. С. 26-31].

Ivannikov V.I., Kuznetsov Yu.I., 2010. Oil: history, origin, patterns of location. Karotazhnik (Well Logger) (9), 114-146 (in Russian) [Иванников В.И., Кузнецов. Ю.И. Нефть: история, происхождение, закономерности размещения // Каротажник. 2010. № 9. С. 114-146].

Karagodin Yu.N., 1980. Sedimentation Cyclicity. Nedra, Moscow, 242 p. (in Russian) [Карагодин Ю.Н. Седиментационная цикличность. М.: Недра, 1980. 242 с.].

Kontorovich A.E., Surkov V.S., Trofimuk A.A. (Eds.), 1981. Geology of Oil and Gas of the Siberian Platform. Nedra, Moscow, 552 p. (in Russian) [Геология нефти и газа Сибирской платформы / Ред. А.Э. Конторович, В.С. Сурков, А.А. Трофимук. М.: Недра, 1981. 552 с.]

Larkin V.N., Valchak V.I., 2007. Forecasting of new zone of oil and gas accumulation in the south-west of Eastern Siberia. Geologiya Nefti i Gaza (Oil and Gas Geology) (1), 24-31 (in Russian) [Ларкин В.Н., Вальчак В.И. Прогнозирование новых зон нефтегазонакопления на юго-западе Восточной Сибири // Геология нефти и газа. 2007. № 1. C. 24-31].

Melnikov N.V., Shemin G.G., Efimov A.O., Safronova I.G., 1981. Cyclostratigraphy of the Vendian and the Lower Cambrian of the South of the Siberian platform. Geologiya i Geofizika (Soviet Geology and Geophysics) 22 (2), 32-47 (in Russian) [Мельников Н.В., Шемин Г.Г., Ефимов А.О., Сафронова И.Г. Циклостратиграфия венда, нижнего и среднего кембрия юга Сибирской платформы // Геология и геофизика. 1981. Т. 22. № 2. С. 32-47].

Melnikov N.V., Shemin G.G., Ostashevsky B.B., 1978. The cyclicity of the Cambrian deposits of the Prilensky region of the Nepa-Botuobinskaya anteclise. Geologiya i Geofizika (Soviet Geology and Geophysics) 19 (7), 9-14 (in Russian) [Мельников Н.В., Шемин Г.Г., Осташевский Б.Б. Цикличность кембрийских отложений Приленского района Непско-Ботуобинской антеклизы // Геология и геофизика. 1978. Т. 19. № 7. С. 9-14].

Ramsay J.G., Huber M.I., 1987. The Techniques of Modern Structural Geology. Volume 2: Folds and Fractures. Academic Press, London, $391 \mathrm{p}$.

Romanovsky S.I., 1988. Physical Sedimentology. Nedra, Leningrad, 240 p. (in Russian) [Романовский С.И. Физическая седиментология. Л.: Недра, 1988. 240 с.].

Shemin G.G., 2007. Geology and Petroleum Potential of Vendian and Lower Cambrian Deposits in the Central Areas of the Siberian Platform. Siberian Branch of RAS Publishing House, Novosibirsk, 467 p. (in Russian) [Шемин Г.Г. Геология и перспективы нефтегазоносности венда и нижнего кембрия центральных районов Сибирской 
платформы (Непско-Ботуобинская, Байкитская антеклизы и Катангская седловина). Новосибирск: Изд-во CO PAH, 2007. 467 c.].

Sokolov B.A., 2001. New Ideas in the Oil and Gas Geology. Selected Works. Moscow State University Publishing House, Moscow, 480 p. (in Russian) [Соколов Б.А. Новые идеи в геологии нефти и газа. Избранные труды. М.: Изд-во Московского госуниверситета, 2001. 480 c.].

Vorobyov V.N., Moiseev S.A., Topeshko V.A., Sitnikov V.S., 2006. Oil and gas fields of the central part of the Nepa-Botuoba anteclise. Geology, Geophysics and Development of Oil and Gas Fields (7), 4-17. (in Russian) [Воробьёв B.H., Mоисеев С.A., Топешко B.A., Ситников В.C. Месторождения нефти и газа центральной части Непско-Ботуобинской антеклизы // Геология, геофизика и разработка нефтяных и газовых месторождений. 2006. № 7. С. 4-17].

\section{Maria R. Marsanova}

Senior Lecturer

M.K. Ammosov North-Eastern Federal University

50 Kulakovsky street, Yakutsk 677000, Russia

e-mail: marigotov@mail.ru

(iD) https://orcid.org/0000-0003-0961-7181

\section{Anatoly G. Berzin}

Doctor of Geology and Mineralogy, Professor

M.K. Ammosov North-Eastern Federal University

50 Kulakovsky street, Yakutsk 677000, Russia

e-mail: a_berzin@mail.ru

(iD) https://orcid.org/0000-0002-3823-9055

\section{Мария Романовна Марсанова}

старший преподаватель

Северо-Восточный федеральный университет им. М.К. Аммосова 677000 , Якутск, ул. Кулаковского, 50, Россия

\footnotetext{
Анатолий Георгиевич Берзин

докт. геол.-мин. наук, профессор

Северо-Восточный федеральный университет им. М.К. Аммосова 677000, Якутск, ул. Кулаковского, 50, Россия
} 